（1）混合時間および偏差を最小にするような最適回転 速度は一般的に充てん量に依存する。

（2）比較的流動性のある粒子の混合では粒径比および 粒子 1 個の質量比が小さいほど良い混合状態が 得られ る。

（3）粒子相互間の摩擦力の大きい系（ポリエチレンペ レットー粟) は大きい回転数を必要とし, 最小偏差值も 大きい。また，上記(2)も適用できない。

（4）本報告で比較した範囲内では，大形の方が良い混 合状態が得られた。

（5）最適回転速度にお忤るフルード数は $1.3 〜 1.9 \times$
$10^{-2}$ となり, 従来 $\mathrm{V}$ 形混合機に与えられていた值 7.6〜 $10 \times 10^{-3}$ よりも多小大きめの值となった。小形の V 形 混合機の実験結果と比較して, 装置が大きいと最適フル 一ド数も大きくなると推察された。

（6）かく拌翼を取り付けることによって混合を促進す ることができるが，今後いっそう幅広い検討が必要であ る。

\section{（謝辞）}

本実験の御指導をいただきました静岡大学の狩野武先 生と，実験装置について御援助いただきました德寿工作 所命尾寿一会長に謝意を表わします。

\section{引用 文 献}

1) Sawahata, Y.: Kagaku Kōgaku (Chem. Eng., Japan), 30, 1140(1966)

2) Sawahata, Y.: Kagaku Kögaku (Chem. Eng., Japan), 31, 1212(1967)

3) Sawahata, Y.: Kagaku Kögaku (Chem. Eng., Japan), 33, 195(1969)

4) Yano, T., I. Kanise and K. Tanaka: Kagaku Kōgaku (Chem. Eng., Japan), 20, 156(1956)

5) Yano, T. and T. Terashita: J. Res. Assoc. Powder Tech., 11, 392(1974)
6) Meio, A.: J. Res. Assoc. Powder Tech., 5, 986 (1968)

7) Williams, J.C. and M.I. Khan :Chemical Engineer, Jan., 19(1973)

8) Patterson-Kelly Co. Catalog : "Chem Eng Catalogue" (1953-54) Reinhold Publishing Co.

9) Oyama, Y. and K. Endoh: "Kotai no Kongo" ZokuShin-Kagakukogaku-Koza 15, p.55(1960)

10) Yano, T. and I. Kanise: Funtai no Kongo in "Funtai Riron to Oyo". p.498(1962)

\title{
参考・資 料
}

\section{常温，常圧下におけるプラズマ発生方法を利用した プラクティブラインによる粉粒体の活性化処理}

Plasma Activation Treatment of Powder by "PLACTIVELINE"

斎 藤 俊 行*

Toshiyuki SAITO

1.はじめに

固体表面を化学反応あるいは物理的処理により活性化 させて, 親水性, 親媒性あるいは易分散性を高めるな ぞ，表面の性質をより合目的に改善する手段として種々 の表面改質技術がある。ここに紹介する『プラクティブ

昭和58年10月27日受付

*三協電業(株)（テ164 東京都中野区本町1-14-13 成子ビル）

TE L $03-372-8911$

**東京理科大学薬学部（テ162 東京都新宿区市ヶ谷船河原町12）

TE L $03-268-3045$
渡 辺 金之助* 小石 真 純**

Kinnosuke WATANABE Masumi KOISHI て生じる部分破壊(コロナ放電)の際に生成される沿面ス トリーマを用いて豊富なプラズマ源を面状に生成させ, これらを種々の固体表面に照射することによって，活性 化処理を行うものである。この手段は, 現在, さかんに 研究報告がなされ，大いに発展が期待されるグロ一放電 を用いた低温プラズマ処理”に比べ，困難とされていた 粉粒体表面の改質処理に対し, 高速処理や量産化が可能 で工業用として十分期待できるものである。これは低温 プラズマ処理法が，真空に近い環境下でのグロー放電に 


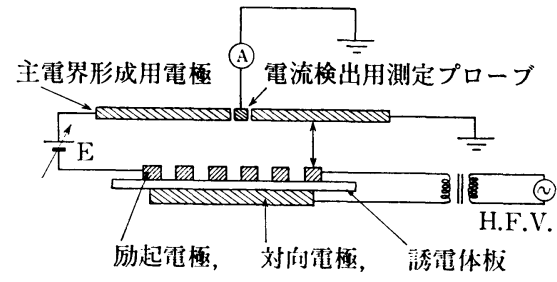

図 1 プラクティブラインプラズマ発生電極, イオン電流密度測定概略図

よって生成されるプラズマ源を用いるのに対し，プラク ティブラインでは, 大気中であっても, 豊富なプラズマ 源を生成できる点に起因している2,31。

本報告は，このプラクティブラインによる活性化手段 を紹介すると共に，その種々の効果を述べ，さらにこ らした表面改質活性化の進展程度を把握する方法として 開発した表面改質度測定装置『アクティテスタ』につい て報告する。

\section{2. プラクティブラインの原理および構造 $2,3,6$}

図1の下部は，大気中でプラズマ源を生成させるため の電極構成の一例を示す。ストリップ状や線状の曲率半 径の著しく小さい励起電極と平板状の対向電極を誘電体 を介して設置し，両者電極間に交流高電圧を印加する構 造からなる。印加電圧の上昇とともに励起電極尖端部で 部分的な気体の絶縁破壊が生じ, 同時に誘電体表面に沿 面ストリーマがステップ状に進展して, 誘電体表面にプ ラズマが生成される。その励起状態では, 大気中であれ ば紫色に上く発光し, それを拡大して観測すると, 細か く長く伸びたストリーマの無数の集合であることが観察 される。励起電極幅をさらに著しく狭く取ることによっ て,プラズマ有効面積が高まり, ほぼ面状プラズマ源のよ らな状態になった。プラズマの内部は豊富な電子と正イ オンからなるが，電子は電界に引かれて外部空間に現わ れ, 気体中では, 電子付着性をもったガス分子 $\left(\mathrm{O}_{2}, \mathrm{H}_{2} \mathrm{O}\right)$ などにトラップされて負イオンとなると考兄られる。

\section{3. イオン電流供給能カ4)}

図 1 上部は, 励起電極と上部に設置した主電界形成用 平板電極間に直流電圧を印加し, 空間に電界を形成させ て, プラズマ源から単極性イオン電流を引き出し, その イオン電流を主電界形成電極内に設置したプローブによ って測定する構成の概略を示す。図 2 にプラズマ発生電 極構成が最適とされる場合のイオン電流密度 $J$ と空間電 界強度 $E$ との関係の測定結果を示す。電流密度はコロナ 放電によって通常得られる電流密度よりも一桁高く, さ

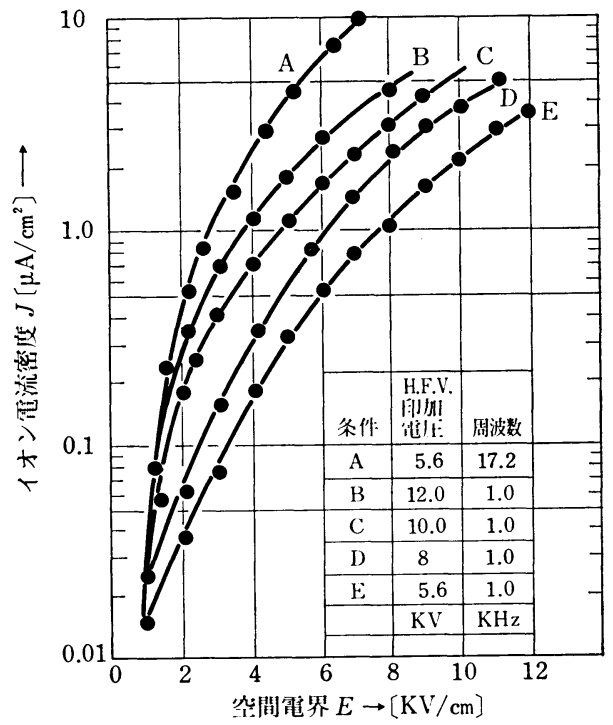

図 2 イオン電流密度測定結果

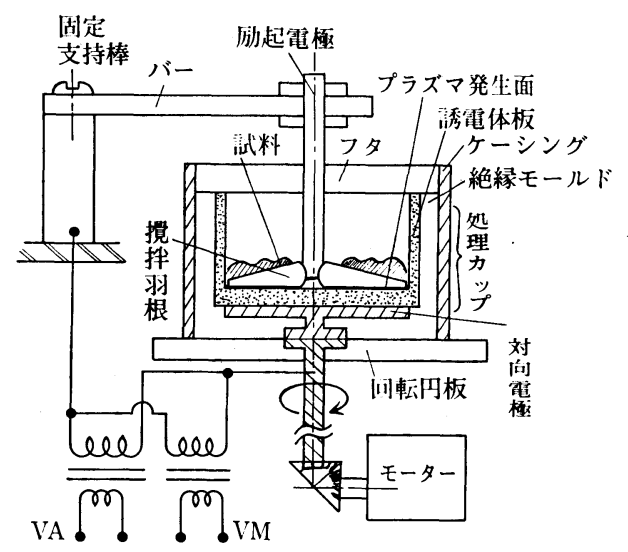

図 3 プラクティブライン $\mathrm{ACB}$ 型の構造

らにJはEの上昇と共に増加するが，やがてその上昇率 は鈍化し飽和傾向に至る。同電圧では高周波数の方が高 い傾向があるが, 飽和電流值は数 $+\left[\mu \mathrm{A} / \mathrm{cm}^{2}\right]$ のオーダ で, 概算される励起電極面上の $1 \mathrm{~cm}^{2}$ 当り 1 秒間に発生 する抽出可能なイオン密度は約 $10^{11}\left[\right.$ 個 $\left./ \mathrm{cm}^{2} \mathrm{sec}\right]$ とな り, それは活性化処理の量産性や高速処理の可能性を裏 付けるに十分なイオン電流供給能力であると考えられ る。

\section{4. プラズマ照射方法}

図 3 は，数十〜数百 $\mathrm{g}$ の粉粒体活性化処理 を対象 と し, 実用化されているバッチ式プラクティブラインの構 
表 1 未処理試料との比較結果

\begin{tabular}{|c|c|c|c|c|c|}
\hline No. & 試料名 ( $A=$ 平均粒径) & 実験方法 & 処理時間 & 結果評価 & 観 測 備 考 （写 \\
\hline 1 & ナイ $\stackrel{\square}{(A=5 \mu \mathrm{m})} 12$ 球 & 図 3 & $t=1 \sim 2$ 分 & 0 & 水に分散した際, 親水性を示し分散した。 \\
\hline 2 & $\begin{array}{r}\text { カーボンフ } \\
\quad(A=0 .\end{array}$ & 図 4 & $t=3 \sim 4$ 分 & & $\begin{array}{l}\text { 水に分散し，試験管を振ったところ，処理 } \\
\text { かく分散しているのが判明した。 }\end{array}$ \\
\hline 3 & $\begin{array}{c}\text { 炭酸カルジウム } \\
(A=0.3 \mu \mathrm{m})\end{array}$ & 図 3 & $t=1 \sim 2$ 分 & & $\begin{array}{l}\text { 水に分散し,試験管を振ったところ, 細カ } \\
\text { エターノール水溶液中では・の程度で }\end{array}$ \\
\hline 4 & 黄 $(A=100 \mu \mathrm{m})^{\text {銅 }}$ 粉 & 図 4 & $t=3 \sim 4$ 分 & & $\begin{array}{l}\text { 水に分散し, 試験管を振ったところ著しい親水性を示 } \\
\text { した。 }\end{array}$ \\
\hline 5 & $\begin{array}{l}\text { 四弗化エチレン } \\
(A=10 \sim 30 \mu \mathrm{m})\end{array}$ & 図 3 & $t=12$ 分 & & $\begin{array}{l}\text { 試験管を強く振ったところ水に分散し, 親水性を示し } \\
\text { た。 }\end{array}$ \\
\hline 6 & $\begin{array}{l}\text { ポリエチレン 粒子 } \\
(A=10 \sim 50 \mu \mathrm{m})\end{array}$ & 図 3 & $t=1$ 分 & e & $\begin{array}{l}\text { 水に分散し試験管を振った後, 分散がよいので沈降速 } \\
\text { が大きい。 }\end{array}$ \\
\hline
\end{tabular}

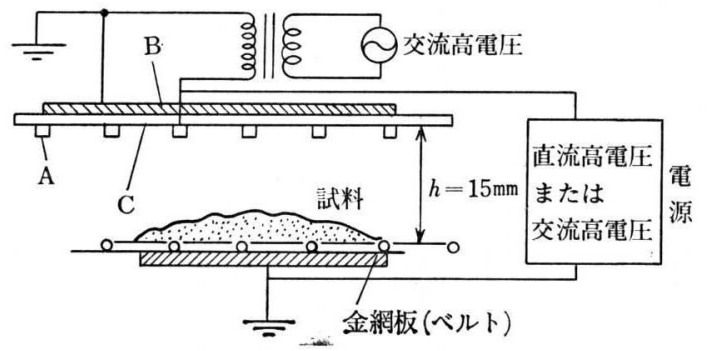

$\mathrm{A}$ : 励起電極, $\mathrm{B}$ : 対向電極, $\mathrm{C}$ : 誘電体板

図 4 イオン照射方法概略図

成の概略を示す。試料を入れる処理カップと，処理の均 一性を高めるため，これを回転させるテーブルから構成 されており，処理カップ内壁は誘電体で覆われ，さらに 対向電極が処理カップ内壁, 誘電体の底部の裏面に密着 して絶縁モールド層内部に設置されている。励起電極は 固定支持棒を支点として円弧移動可能なバーによって, 処理する試料を擋拌しながら誘電体表面間に強力なプラ ズマ領域を形成する。本装置では励起電極自身が移動 し, 粉粒体擋拌機能を備えているところに特長がある。

また，カーボンブラックや金属粉粒体のような酸化し やすい導電性の高いものについては, 図 4 に示すよう に，上部にプラズマ源を設置し，下部に試料を供給さら に均一にイオン照射が行なえるよう金網板を左右に移動 させて擋拌させ処理した。

\section{5. 処理 結果}

表 1 に未処理の粉粒体試料を精製水の入った試験管に 入れ，プラズマ処理した同試料との親水性，分散性，凝 集性を観察した結果を示す。表中, 結果評価の「の」の

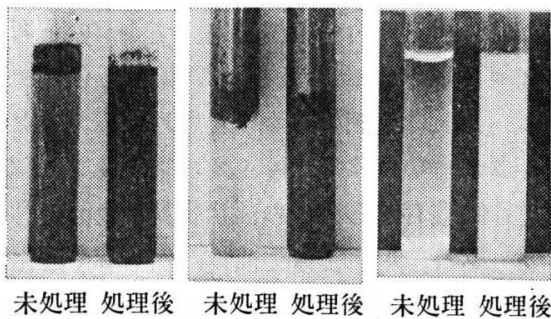

$\begin{array}{llll}\text { (a) カーボンブラック } & \text { (b) 黄銅粉 } & \text { (c) 炭酸カルシウム }\end{array}$ 図 5 処理結果写真

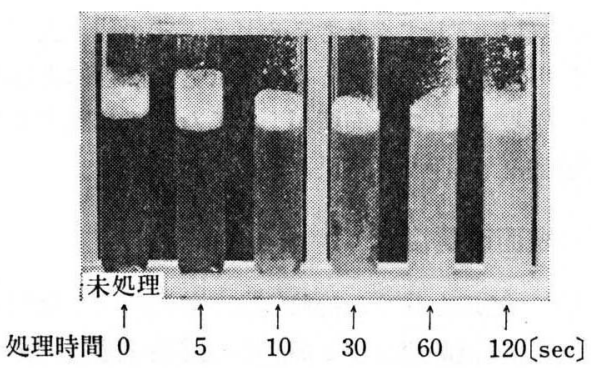

図 6 ナイロン12球による処理時間の違いによる比較

数は効果の程度を表わす。図 5 は，その結果の様子を示 す。いずれも表 1 の観測備考に示すとおり, 未処理に比 べ著しい親水性の向上が明らかに観察されている。ま た，図 6 に示す写真は図 3 の方法および，同条件でナイ ロン12球を処理したときの処理時間と処理効果を示す写 真である。処理効果は処理時間数秒から現われ, $1 \sim 2$ 分で良好な易分散性を示す。有効な処理効果が観察され る最小処理時間「 $t_{s} 」$ は, ポリエチレン，ナイロン 12 球, テレフタル酸試料についてはいずれもほぼ $1 \sim 2$ 分 以内であり，四フッ化ェチレン粉粒体では 15 分程度で 
あった。これらの処理時間は,グロー放電を用いた低温 プラズマ処理では, 同様な効果を得るのに数時間を要す るのに対しきわめて短い。

\section{6. 考 察}

上記の各種プラクティブラインによる実証例は, いず れも大気中で行ったものの処理効果の一部を示したが， (1)親水性の向上, (2)親液性の向上, (3)付着, 接着性の向 上, (4)易分散性の向上, (5)物性表面の異質物の除去, (6) エッチング効果, など著しい効果が生じることが判明し た。これらの現象論については, 表面状態の分析などに よる追求が必要であるが，ここでは推定される諸反応を 簡単に述べるにとどめる。化学的変化としては, ごくわ ずかな電子と大気中の分子との衝突によって生じた活性 種によって, 粉子表面層で, $\mathrm{OH}$ 基などの化学結合の組 み換えが行われ，重合や架橋が進展するものと考えられ る。ナイロン 12 球, ポリエチレン, 四フッ化エチレンに ついてはこれに起因するものと思われる。またカーボ ンブラックについては, ファーネスブラックであるた め, 製造中に残存する微量の油状物質が表面に付着して おり，プラズマ照射によって油膜が熱分解や酸化，また は除去作用などが働き，コロイダルカーボンになること により, また，黄銅粉については，ステアリン酸金属石 齢で表面処理されているため, 照射によってステアリン 酸膜が上記と同様, 酸化されたり, 除去されることによ って親水性が向上すると考えられる。その他, 表面のキ ヤピラリ一部分に付着する水分子などが照射によって除 去され，見かけ上の表面積が上がるなどに起因すること や，表面凹凸が進んだ結果などが考えられる。

\section{7. 表面改質度計}

プラズマ処理を受けた粉粒体は，前述のような種々の 形態で表面改質が進展するが，この進展状態にマクロな 電気的物性を測定することによりとらえることが可能で あるかを検討した。

\section{1 実験方法}

図 7 に概略の一例を示す。マイクロフィーダによって 一定量供給された被試料粉粒体は, 分散機に供給され, プロペラの高速回転から生ずる乱流によって単分散さ れ, 強制荷電装置 (ボクサーチャージャ) 4 (,5) に導びかれ る。これは交流電界内で, 沿面放電により左右から豊富 な単極性イオンを供給し，その空間を通過する粉粒体 に, 双方向からイオン射突を行い, 粒子表面積に比例し た理論的飽和带電量に荷電するものである。荷電された 粉粒体粒子を，下部に設置された吸引ファラデーケージ

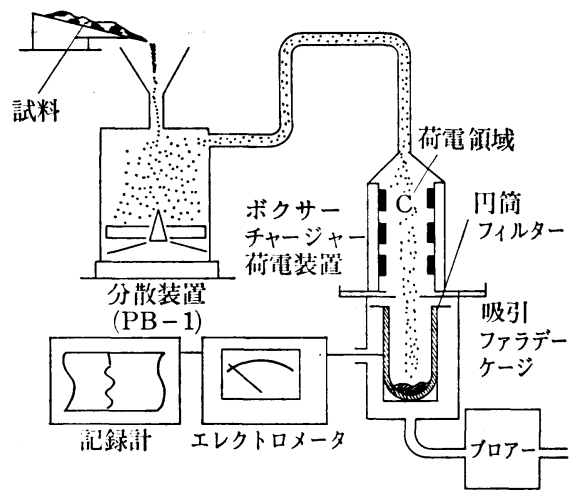

図 7 改質度計『アクティテスタ』の概略構成図

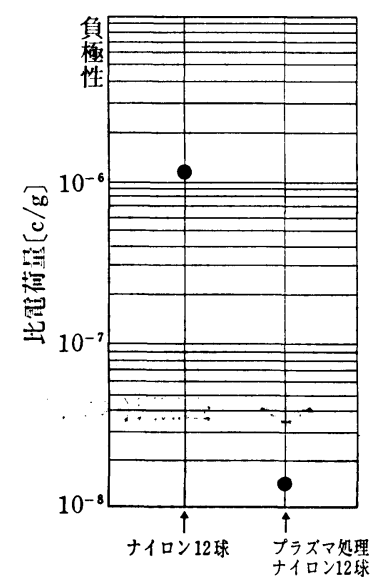

図 8 改質度計アクティテスタによる測定結果

のフィルタ内に捕集し，その持ち込及電荷量を計測す る。さらに捕集された粉粒体重量を測定し, 比電荷 $Q$ / $M$ を算出する。試料としてナイロン12球を用いた。荷電 の極性は負極性を用いた。

\section{2 測定結果と評価}

図 8 に測定結果の一例を示す。未処理試料の比電荷量 は， $1.32 \times 10^{-6}[\mathrm{c} / \mathrm{g}]$ に計測されるが，同条件でプラズ マ処理を行った粒子の比電荷は, $1.40 \times 10^{-8}[\mathrm{c} / \mathrm{g}]$ を示 し，二桁低い值を示している。これは，プラズマ処理を 受けた粉粒体の表面改質の結果生じる電気的物性変化, たとえば，見かけ上の誘電率や表面抵抗率の変化による ものと考えられ，また，上記の相違值は粉粒体改質進展 過程を把握するに十分な電気量であることを示してい る。上記の構成は，連続的な瞬時計測が可能であること から，表面改質モニターとして，またプロセス中におけ る改質度計として十分利用できる7。 


\section{8. おわりに}

大気中のプラズマ照射による粉粒体の新しい表面改質 手段を見い出し，定性的な評価を行って高速処理の可能 性を検討した。また, 親水性の向上, 親液性の向上, 易
分散性の向上など，著しい効果があることを実証した。 さらにこの手段は他の気体中常圧下でも行えるため，モ ノマー重合による活性化効果も十分期待でき，今後大い に発展するものと考えられる。

\section{参 考 文 献}

1）筏義人：低温プラズマによる表面処理, 洗浄設計, pp. 18 28(1982)

2) 阿久津顕右 : 粉体表面物性評価の計測技術, 電気的物性 測定技術，粉体技術会議（1982）

3）阿久津顕右, 小石真純 : 新型荷電に上る浮遊粉粒体の物 性測定法, 第 2 回空気清浄研究大会 (1983)

4) Masuda, S., K. Akutsu and T. Saito: Electrostatic Continuous Dust Monitor Using Boxer-Charger, Record of IEEE/IAS 1980 Annval Meeting (Oct, 1980 in Cincinati, Ohi)

5) Masuda, S., M. Washizu, A. Mizuno and K. Akutsu: Boxer-Chager-A Novel Charging Device for High Resistivity Powders, Record of IEEE/ IAS, 1978, Annual Meeting, p16 Oct. 1978 Tronto, Canada

6）阿久津顕右, 小石真純：プラスチックの表面改質とその 物性評価, 瀻維学会年次大会 (1983)

7) プラズマによる各種材料の改質: 特集, 工業材料, Vol. 31, NO.7(1983) 